\title{
Deferoxamine Promotes MDA-MB-231 Cell Migration and Invasion through Increased ROS-Dependent HIF-1 $\alpha$ Accumulation
}

\author{
Yiping Liua, a,d Yongfeng Cui ${ }^{\mathrm{b}, d}$ Miao Shib ${ }^{\mathrm{a}}$ Qiang Zhang ${ }^{\mathrm{b}}$ Qiang Wang ${ }^{\mathrm{a}}$ \\ Xiaodong Chen ${ }^{b}$
}

${ }^{a}$ Center of Hygiene Assessment and Research, Institute of Disease Control and Prevention, Academy of Military Medical Sciences, Beijing, 'Department of Physiology, BaoTou Medical College, Inner Mongolia University of Science and Technology, Baotou, 'Beijing Municipal Public Security Hospital, Beijing Municipal Public Security Bureau, Beijing, China; ${ }^{\mathrm{d}}$ These authors contributed equally to this work

\section{Key Words}

Deferoxamine $\cdot$ Hypoxia-inducible factor- $1 \alpha \cdot$ Reactive oxygen species $\cdot$ Extracellular signalregulated kinase $1 / 2 \cdot$ Breast cancer

\begin{abstract}
Background/Aim: Deferoxamine (DFO), an iron chelator, has been reported to induce hypoxia-inducible factor- $1 \alpha$ (HIF-1 $\alpha$ ) expression. HIF-1 $\alpha$ plays a critical role in promoting tumor metastasis. However, the molecular mechanisms underlying induction of HIF-1 $\alpha$ in breast cancer cells remain unknown. Our aim was to ascertain whether DFO enhanced cancer metastasis in MDA-MB-231 cells. Methods: Cellular reactive oxygen species (ROS) was measured by flow cytometry. Cell migration was determined by wound healing and transwell assays. Protein and mRNA expression were detected by western blotting and RT-PCR, respectively. Results: DFO treatment enhanced cell migration and invasion, while HIF-1 $\alpha$ expression was significantly up-regulated at the post-transcriptional level. However, treatment with a NADPH oxidase inhibitor, diphenyleneiodonium (DPI), strongly inhibited ROS generation and HIF-1 $\alpha$ expression, as well as cell migration and invasion. Notably, DFO treatment increased extracellular signal-regulated kinase (ERK)1/2 phosphorylation. Inhibition of ROS production with DPI attenuated DFO-induced ERK1/2 activation. Moreover, a MEK1 inhibitor, PD98059, suppressed DFO-induced cell migration and invasion. Conclusion: DFO-induced HIF- $1 \alpha$ expression involves a cascade of signaling events including ROS generation, activation of ERK signaling, and subsequent promotion of cell migration and invasion. These findings indicate a risk associated with DFO and other iron chelators for treatment of tumors with invasive potential.
\end{abstract}

Dr. Qiang Wang

and Dr. Xiaodong Chen
Center of Hygiene Assessment and Research, Institute of Disease Control and Prevention, Academy of Military Medical Sciences, 20 Dongda Street, Beijing 100071 (China) Tel.+861066948432, E-Mail wang76qiang@aliyun.com.cn, xiaodongch@sina.com.cn 


\section{Introduction}

Iron $(\mathrm{Fe})$ is an essential element for cellular functions including cell proliferation. Because of their rapid proliferation, tumor cells have an increased requirement for Fe [1]. Recent studies indicate that excess accumulation of Fe may be a risk factor for breast cancer $[2,3]$. Accordingly, breast cancer cells display an abnormal Fe metabolism. For example, breast cancer cells express high levels of transferrin receptor 1 and internalize Fe from transferrin at a very high rate $[4,5]$. In addition, expression of ferritin, transferrin receptors, transferrin, and iron-regulatory proteins 1 and 2 are substantially elevated in breast cancer cells with an aggressive mesenchymal phenotype. These observations suggest that Fe imbalance is associated with the progression of breast cancer toward a more advanced malignant phenotype [6]. Thus, targeting cancer with chelating agents in an attempt to alter cellular Fe homeostasis or metabolism is a promising treatment approach $[7,8]$.

Fe chelation has been examined both in vitro and in vivo as a therapeutic intervention for breast cancer [9-11]. Deferoxamine (DFO) was the first Fe chelator to be examined for antitumor effects. It primarily causes a reduction in total body Fe by chelating extracellular Fe. However, Fe depletion by DFO has been shown to increase hypoxia-inducible factor-1 alpha (HIF-1 $\alpha$ ) expression $[12,13]$. HIF- $1 \alpha$ is a critical mediator of the physiological response to hypoxia, and its dysregulation promotes tumor angiogenesis and metastasis [14]. Moreover, primary breast cancer biopsies have revealed that high expression of HIF- $1 \alpha$ is associated with significantly increased risks of treatment failure, disease relapse, distant metastasis, and patient mortality [15-17]. Thus, clinical Fe chelation therapy may have unintended effects including promotion of tumor metastasis by increasing HIF-1 $\alpha$ expression.

Reactive oxygen species (ROS) has been implicated in the aggressive behavior of cancer cells, but its role in the regulation of HIF- $1 \alpha$ expression appears to be controversial. Increased HIF- $1 \alpha$ expression has been found to contribute to mitochondrial activity and specifically ROS formation during hypoxia [18-20]. More importantly, ROS derived from NADPH oxidases can be produced in the cytosol $[21,22]$. In addition, it plays a larger role in HIF$1 \alpha$ expression during normoxia than hypoxia [23]. Under normoxic conditions, PI-3K/Akt and MEK1/extracellular signal-regulated kinase (ERK) pathways modulate HIF-1 activation by basic fibroblast growth factor (bFGF) in human breast cancer cells [24]. Conversely, other studies have demonstrated a decrease in HIF-1 $\alpha$ expression with increasing ROS [25, 26]. Furthermore, some studies have shown no effects on mitochondrial ROS [27]. These contrasting results suggest that it is important to focus on the relationship between HIF-1 $\alpha$ and ROS in breast cancer.

We hypothesized that DFO could promote breast cancer cell migration and invasion through accumulation of HIF-1 $\alpha$, which contributes to the metastatic process. In the present study, we investigated the effects of DFO on cell migration and invasion in a breast cancer cell line. We also characterized the association between the treatment and ROS activity, as well as the expression of HIF- $1 \alpha$ and downstream genes. Furthermore, we explored the role of the ERK1/2 pathway in DFO-induced cell migration and invasion in vitro.

\section{Materials and Methods}

\section{Cell culture}

All the experiments were performed in a biology laboratory of the Institute of Disease Control and Prevention of People's Liberation Army (Beijing, China). The human breast cancer cell line MDA-MB-231 was purchased from the American Type Culture Collection (Manassas, VA, USA). The cells were cultured in Dulbecco's modified Eagle medium (DMEM) supplemented with 10\% fetal calf serum, $100 \mathrm{U} / \mathrm{ml}$ penicillin, and $100 \mu \mathrm{g} / \mathrm{ml}$ streptomycin at $37^{\circ} \mathrm{C}$ in a humidified atmosphere with $5 \% \mathrm{CO}_{2}$. 
Cytotoxicity assay

Cells $\left(4 \times 10^{4}\right)$ were seeded in 96 -well culture plates and allowed to adhere overnight at $37^{\circ} \mathrm{C}$. The cells were then incubated in medium $(100 \mu \mathrm{L})$ containing 30 or $300 \mu \mathrm{M}$ DFO. Control cells were not exposed to DFO. After 24 hours of incubation, the growth medium was exchanged with $100 \mu \mathrm{L}$ MTT (3-(4,5-dimethylthiazol2-yl)-2,5-diphenyltetrazolium bromide) reagent in DMEM, and the cells were incubated for 3 hours at $37^{\circ} \mathrm{C}$. Cells viability was analyzed by measuring the absorbance at $570 \mathrm{~nm}$ with a microplate reader.

\section{ROS detection}

Cellular ROS was measured by flow cytometry using $\mathrm{H}_{2}$ DCF-DA as a fluorescent probe. The cells were incubated with $10 \mu \mathrm{M}$ H2DCF-DA for 30 minutes at $37^{\circ} \mathrm{C}$, washed, resuspended in phosphate-buffered saline, and then analyzed by a FACSort (BD Biosciences, San Jose, CA, USA). The mean fluorescence intensity was quantified by CellQuest software (BD Biosciences, San Jose, CA, USA).

\section{Wound healing assay}

MDA-MB-231 cells were seeded in 6-well plates and cultured to 80-90\% confluence. The monolayer was then wounded by dragging a plastic pipette tip across the surface. Then, the cells were incubated with medium containing 30 or 300 DFO, $300 \mu \mathrm{M}$ DFO + $100 \mu \mathrm{M}$ diphenyleneiodonium (DPI), or $300 \mu \mathrm{M}$ DFO + $100 \mu \mathrm{M}$ PD98059. The control cells were not exposed to DFO. After 24 hours of incubation, phase contrast images of the wounds were recorded, and cells that had migrated into the wounded areas were counted to quantify the cell migration.

\section{Transwell invasion assay}

Migration of MDA-MB-231 cells was determined using transwell chambers (24-well plates, 8- $\mu \mathrm{m}$ pore size, Corning). Cells $\left(1 \times 10^{5}\right)$ were loaded into the upper chamber containing medium with 30 or $300 \mu \mathrm{M}$ DFO, $300 \mu \mathrm{M}$ DFO $+100 \mu \mathrm{M}$ DPI, or $300 \mu \mathrm{M}$ DFO $+100 \mu \mathrm{M}$ PD98059. After 24 hours of incubation, the cells were fixed and stained with $0.1 \%$ crystal violet. The number of cells that migrated to the underside of the membrane was counted under a light microscope. Three independent experiments were carried out in triplicate.

\section{Semi-quantitative RT-PCR}

Total RNA from the cells was isolated using Trizol (Invitrogen, CA, USA). Reverse transcription was performed with a PrimeScript ${ }^{\circledR}$ II 1st Strand cDNA Synthesis Kit (TaKaRa, Dalian, China) according to the manufacturer's instructions. The primer sequences (Invitrogen, Shanghai, China) were as follows: HIF-1 $\alpha$, (forward) 5'-GCACAGGCCACATTCACG-3' and (reverse) 5'-TGAAGATTCAACCGGTTTAAGGA-3'; vascular endothelial growth factor (VEGF), (forward) 5'-TGCCCGCTGCTGTCTAAT-3' and (reverse) 5'-TCTCCGCTCTGAGCAAGG-3'; 3-phosphoinositide-dependent protein kinase-1 (PDK1), (forward) 5'-TGAACTGACCTTGCCACAT-3' and (reverse) 5'-TGAAGCAGCACTGAACACG-3'; glyceraldehyde-3-phosphate dehydrogenase (GAPDH), (forward) 5'-AAGGTCATCCCTGAGCTGAA-3' and (reverse) 5'-CCCCTCTT CAAGGGGTCTAC-3'. PCR was carried out in a $25 \mu$ volume including $1 \times$ PCR buffer, $50 \mathrm{ng}$ cDNA, 25 pmol each of forward and reverse primers, $1.5 \mathrm{mM} \mathrm{MgCl}_{2}, 0.2 \mathrm{mM}$ of each dNTP, and $3 \mathrm{U}$ Taq DNA polymerase. Amplification conditions were denaturation at $95^{\circ} \mathrm{C}$ for 5 minutes, 25 cycles of $95^{\circ} \mathrm{C}$ for 60 seconds, $66^{\circ} \mathrm{C}$ for 60 seconds, and $72{ }^{\circ} \mathrm{C}$ for 60 seconds, followed by a final 10 -minute extension at $72{ }^{\circ} \mathrm{C}$. GAPDH was used as an internal control. RT-PCR products were analyzed by electrophoresis on $1.2 \%$ agarose gels stained with ethidium bromide.

\section{Western blot analysis}

Cells were lysed in RIPA buffer containing a protease inhibitor cocktail (Roche, Switzerland). Total protein $(10 \mu \mathrm{g})$ was separated by $12 \%$ sodium dodecyl sulfate-polyacrylamide gel electrophoresis and then electrotransferred onto nitrocellulose membranes. The blots were blocked using $5 \%$ blocking reagent in Tris-buffered saline with Tween-20 (TBS-T) for 1 hour at room temperature and then incubated with a primary antibody $(1: 1000)$ overnight at $4{ }^{\circ} \mathrm{C}$. After washing with TBS-T, the blots were incubated with a secondary antibody conjugated to horseradish peroxidase (1:1000) for 1 hour at $37^{\circ} \mathrm{C}$. After extensive washing, the complexes were visualized using a West Pico chemiluminescent kit (Pierce, Rockford, IL, USA). 
$\mathbf{A}$

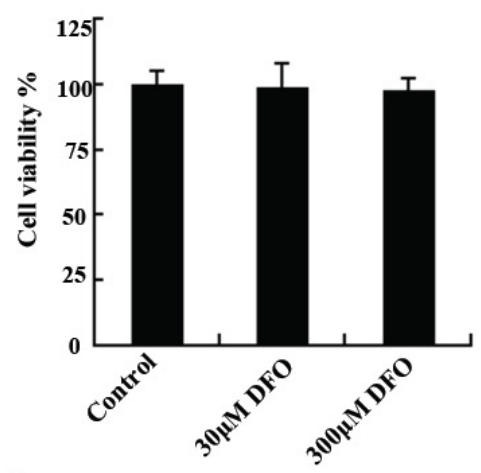

$C$ ค

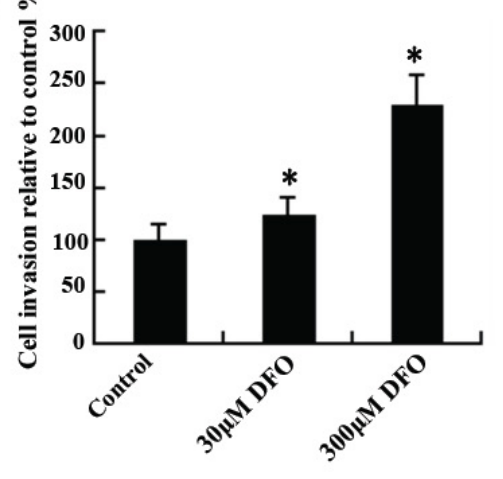

B
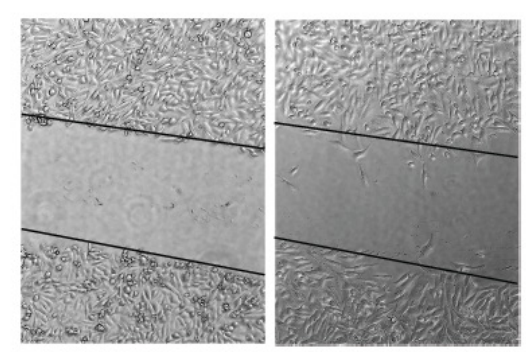

Control
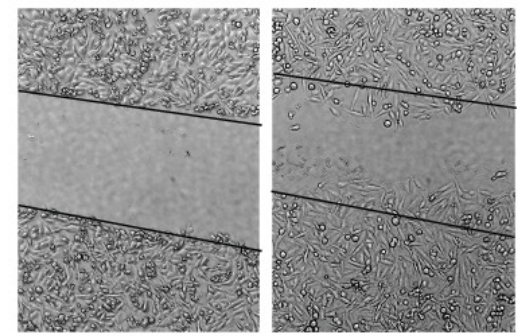

$30 \mu M$ DFO

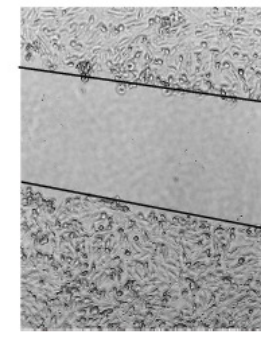

$\mathbf{0 ~ h}$

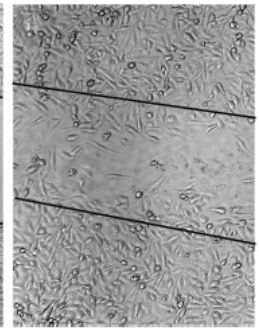

24 h

Fig. 1. DFO treatment enhances the migration and invasion of MDA-MB-231 cells. MDA-MB-231 cells were cultured without or with 30 or $300 \mu \mathrm{M}$ DFO, and then the effect of DFO on cell viability was determined by (A) MTT assays. Results are the mean \pm SD from three independent experiments ${ }^{*} \mathrm{p}<0.05$ compared with untreated cells). (B) Wound healing migration assay of DFO-treated and untreated MDA-MB-231 cells. Distances migrated by DFO-treated and untreated cells were compared in three independent experiments. (C) Invasiveness of MDA-MB-231 cells (treated with or without DFO) was quantified by transwell assays. Results are the mean \pm SD value of three independent experiments $(* \mathrm{p}<0.05$ compared with untreated cells $)$.

\section{Statistical analysis}

Results are expressed as the mean \pm standard deviation (SD). Differences between means were determined by one-way analysis of variance followed by a least significant difference test for multiple comparisons. A p-value of less than 0.05 was regarded as statistically significant.

\section{Results}

DFO promotes cell migration and invasion

Compared with untreated cells, the cell viability was not significantly affected by 30 or $300 \mu \mathrm{M}$ DFO treatment for 24 hours (Fig. 1A). Morphological observation also indicated that 30 or $300 \mu \mathrm{M}$ DFO exhibited no cytotoxicity in MDA-MB-231 cells (data not shown). Thus, the above concentrations and an incubation time of 24 hours were applied in the following experiments. Wound healing and transwell assays were used to assess the effects of DFO on MDA-MB-231 cell migration and invasion. As shown in Fig. 1B, treatment with 30 or $300 \mu \mathrm{M}$ DFO significantly enhanced cell migration in wound healing assays (Fig. 1B). In transwell assays, the results showed a significant increase of cell invasion by treatment with DFO. Compared with untreated cells, 30 and $300 \mu \mathrm{M}$ DFO enhanced MDA-MB-231 cell invasion by 
Fig. 2. DFO increases the $\mathbf{A}$ expression levels of HIF-1 $\alpha$ protein, VEGF mRNA, and PDK1 mRNA in MDA-MB-231 cells. MDA-MB-231 cells were cultured without or with 30 or $300 \mu \mathrm{M}$ DFO. (A) Representative blot and electrophoretogram of HIF- $1 \alpha$ protein and mRNA, respectively. Compared with untreated cells, DFO-treated cells showed higher

A

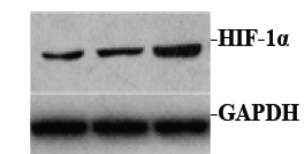

B

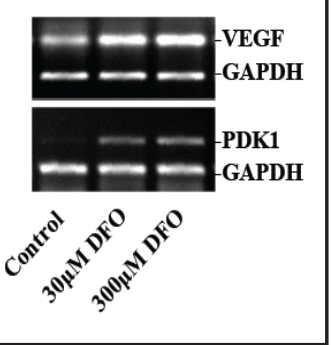
levels of HIF-1 $\alpha$ protein but not HIF-1 $\alpha$ mRNA. (B) Representative levels of VEGF and PDK1 mRNAs. Compared with untreated cells, VEGF and PDK1 mRNA levels were increased in DFO-treated cells.

24 and 129\%, respectively (Fig. 1C). These data indicate that 30 and $300 \mu \mathrm{M}$ DFO promotes cell migration and invasion, but has no significant cytotoxicity in MDA-MB-231 cells.

\section{DFO elevates HIF-1 $\alpha$ protein expression via a post-transcriptional mechanism}

To explore the effects of DFO on HIF-1 $\alpha$ expression, MDA-MB-231 cells were treated with 30 and $300 \mu \mathrm{M}$ DFO. After treatment, HIF-1 $\alpha$ expression was detected by western blot analysis. The results showed up-regulation of HIF-1 $\alpha$ protein expression in cells treated with 30 or $300 \mu \mathrm{M}$ DFO for 24 hours (Fig. 2A). Conversely, treatment with 30 or $300 \mu \mathrm{M}$ DFO had no obvious effect on HIF-1 $\alpha$ mRNA expression (Fig. 2A). Researches of others also demonstrate that Fe depletion by DFO increase HIF-1 $\alpha$ expression in vivo and in vitro $[12,13$, 28]. HIF-1 $\alpha$ transactivates multiple categories of genes to promote tumor growth, including VEGF, one of the most potent angiogenic factors, and PDK1, a metabolic enzyme that converts tumor metabolism to glycolysis by inactivating a tricarboxylic acid cycle enzyme, pyruvate dehydrogenase. To further investigate whether DFO-induced HIF-1 $\alpha$ could up-regulate VEGF and PDK1, we determined their mRNA expression by RT-PCR after 24 hours of DFO treatment (Fig. 2B). As a result, treatment with DFO significantly increased mRNA expression of VEGF and PDK1 in MDA-MB-231 cells, indicating that DFO regulates HIF-1 $\alpha$ expression at the posttranscriptional level.

\section{NADPH oxidase-derived ROS regulates HIF-1 $\alpha$-dependent cell migration and invasion}

We also examined whether ROS plays a role in DFO-induced up-regulation of HIF$1 \alpha$ in MDA-MB-231 cells. Flow cytometric analysis using the fluorescent dye $\mathrm{H}_{2}$ DCF-DA demonstrated that DFO increased the cellular fluorescence intensity compared with that in control cells. Treatment of MDA-MB-231 cells with 30 or $300 \mu$ M DFO increased cellular ROS generation by 28 and 61\%, respectively. The elevated ROS levels were consistent with HIF$1 \alpha$ up-regulation (Fig. 3A). It has been reported that ROS produced from NADPH oxidase is responsible for HIF-1 $\alpha$ stabilization under hypoxic conditions [29]. Treatment of cells with the NADPH oxidase inhibitor DPI $(100 \mu \mathrm{M})$ significantly inhibited cellular ROS generation (Fig. 3B) and attenuated HIF-1 $\alpha$ up-regulation induced by $300 \mu \mathrm{M}$ DFO (Fig. 3C). These results suggest that ROS is responsible for DFO-induced up-regulation of HIF- $1 \alpha$. Accordingly, wound migration assays showed that treatment of the cells with $100 \mu \mathrm{M}$ DPI resulted in a decrease of DFO-induced migratory activity compared with that in DFO-treated cells (Fig. 3D). Similarly, transwell invasion assays indicated a decrease of DFO-induced invasiveness by treatment with DPI compared with that in DFO-treated cells (Fig. 3E). These results strongly indicate that induction of NADPH oxidase activity and subsequent augmentation of ROS generation by DFO treatment might activate HIF-1 $\alpha$-dependent cell migration and invasion. 


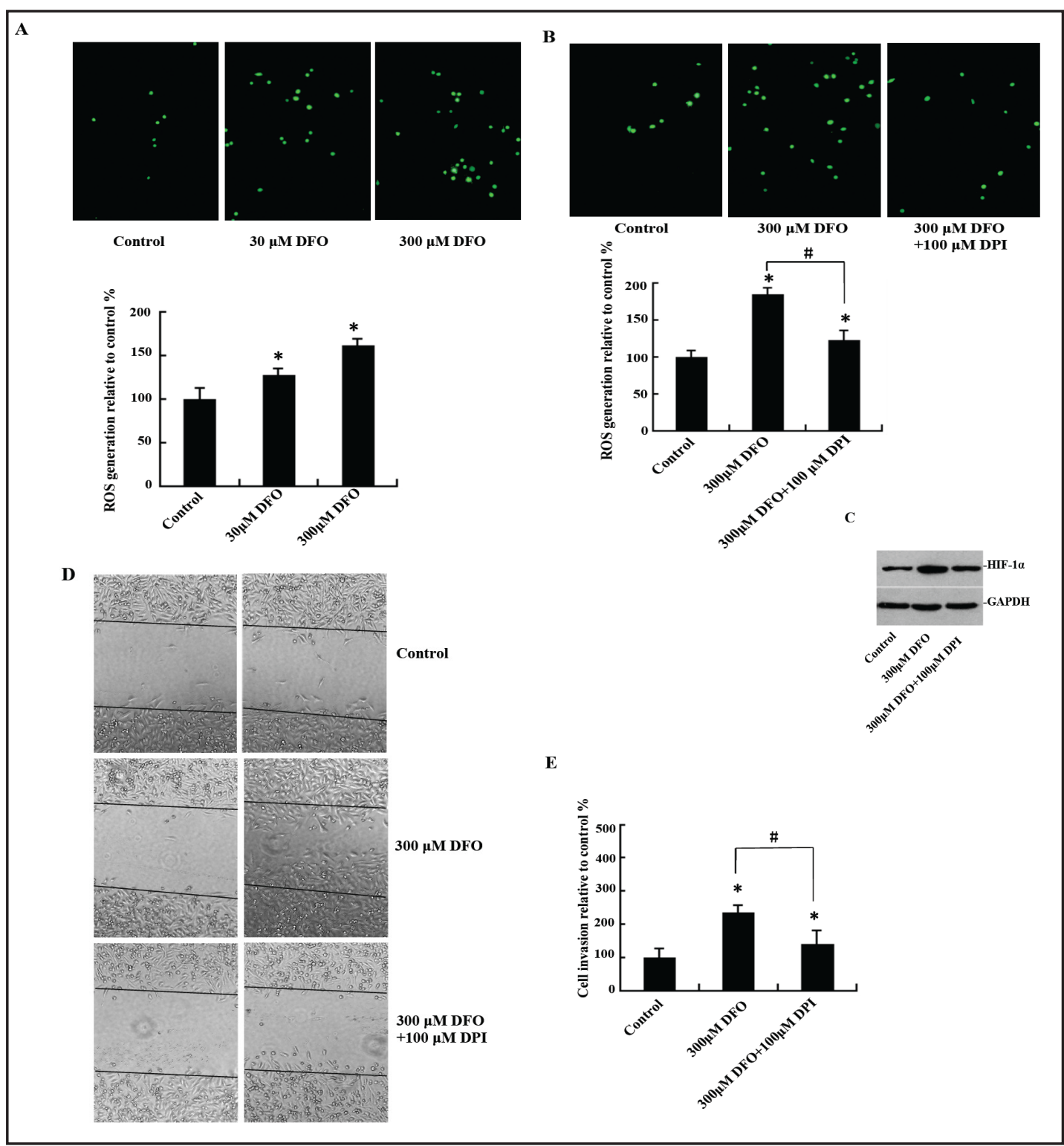

Fig. 3. NADPH oxidase-derived ROS promotes aggressive cellular behaviors by up-regulating HIF-1 $\alpha$ expression. MDA-MB-231 cells were cultured without or with 30 or $300 \mu \mathrm{M}$ DFO, or $300 \mu \mathrm{M}$ DFO $+100 \mu \mathrm{M}$ DPI. (A) DFO treatment of the cells increased ROS generation. The mean fluorescence intensity of MDAMB-231 cells (with or without DFO treatment) was quantified by flow cytometry. Results are the mean \pm SD of three independent experiments ${ }^{*} \mathrm{p}<0.05$ compared with untreated cells). (B) DPI treatment $(100 \mu \mathrm{M})$ effectively attenuated DFO-induced ROS activity. The mean fluorescence intensity of the cells was quantified by flow cytometry. Results are the mean \pm SD of three independent experiments ${ }^{*} \mathrm{p}<0.05$ compared with untreated cells). (C) DPI treatment inhibited DFO-induced HIF-1 $\alpha$ up-regulation. (D) Wound healing assays showed that cells treated with $100 \mu \mathrm{M}$ DPI exhibited a decrease in DFO-induced migratory activity compared with that of DFO-treated cells. (E) Transwell assays showed a decrease in DFO-induced invasiveness by treatment with DPI compared with that of DFO-treated cells. Results are the mean \pm SD of three independent experiments $\left({ }^{*} \mathrm{p}<0.05\right.$ compared with untreated cells; ${ }^{\#} \mathrm{p}<0.05$ compared with DFO-treated cells).

\section{DFO-induced cell migration and invasion is mediated via the ERK pathway}

Because NADPH oxidase 1 transcription is enhanced by the ERK pathway [30], we investigated whether DFO regulates NADPH oxidase through the ERK pathway. Western 
Fig. 4. ERK1/2 pathway mediates DFO-induced cell migration and invasion. MDA-MB-231 cells were cultured without or with $300 \mu \mathrm{M}$ DFO, $300 \mu \mathrm{M}$ DFO + $100 \mu \mathrm{M}$ DPI, or $300 \mu \mathrm{M}$ DFO + $100 \mu \mathrm{M}$ PD98059. (A) ERK1/2 phosphorylation was increased in DFO-treated cells compared with that in untreated cells. Treatment with $100 \mu \mathrm{M}$ DPI down-regulated ERK1/2 activation to near basal levels. (B) Wound healing assays showed that cells treated with $100 \mu \mathrm{M}$ PD98059 exhibited a decrease in DFO-induced migratory activity compared with that of DFO-treated cells. (C) Transwell assays showed a decrease in DFO-induced invasiveness by treatment with PD98059 compared with that of DFO-treated cells. Results are the mean \pm SD of three independent experiments ( $*$ p $<0.05$ compared with untreated cells; \# p<0.05 compared with DFO-treated cells).

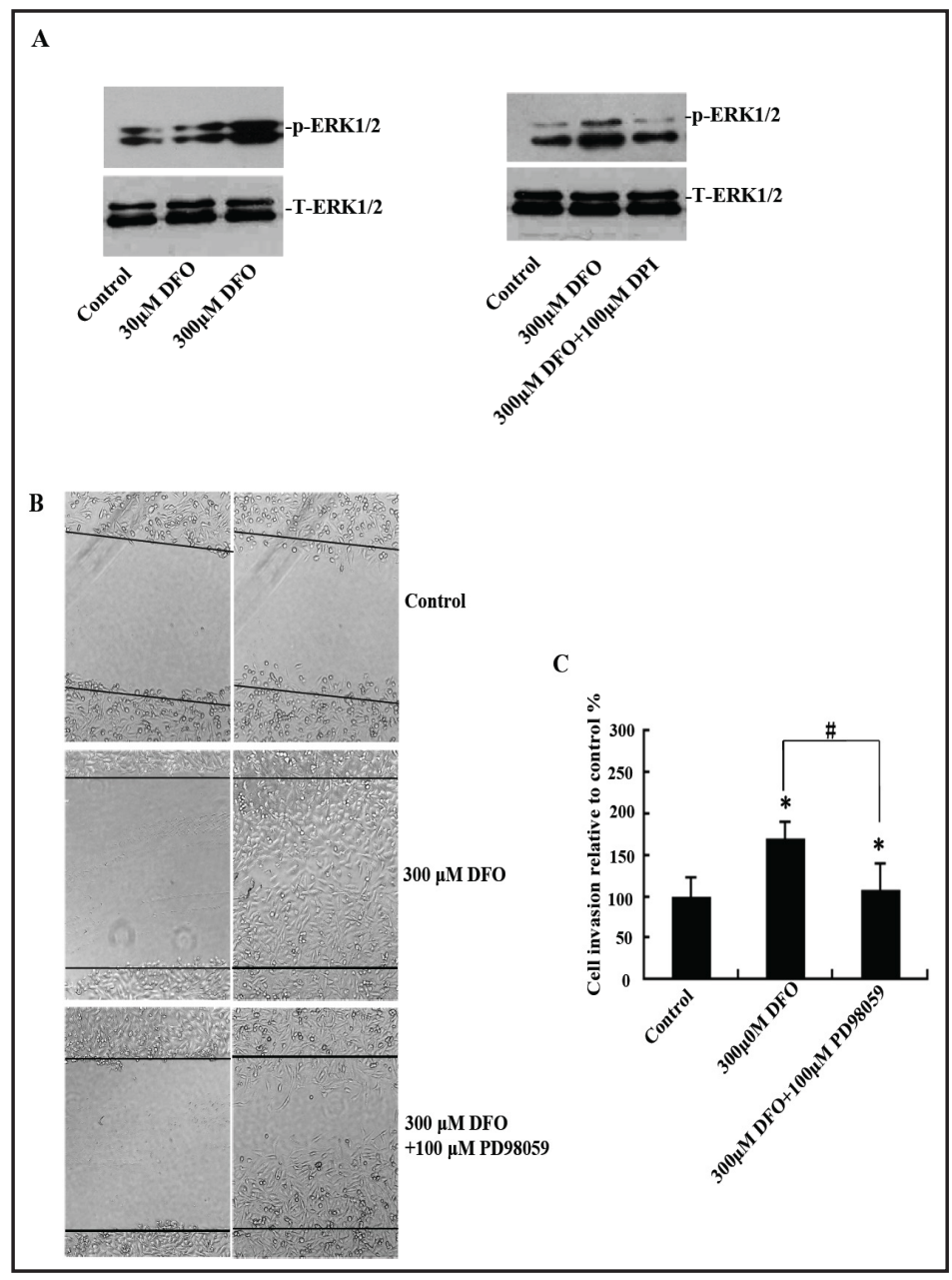

blotting demonstrated that the level of ERK1/2 phosphorylation was aberrantly stimulated in DFO-treated cells (Fig. 4A). Rathnasamy et al. also reported that administration of DFO to hypoxic microglial cells enhanced p-ERK phosphorylation [31]. Treatment with $100 \mu \mathrm{M}$ DPI significantly attenuated DFO-induced ERK1/2 activation to near basal levels (Fig. 4A). There were no changes in the levels of total ERK1/2 following treatment with DFO or DPI (Fig. 4A). Furthermore, wound migration assays showed that PD98059 treatment resulted in a decrease of migratory activity compared with that in DFO-treated cells (Fig. 4B). Similarly, transwell invasion assays indicated a decrease of cell invasiveness compared with that in DFO-treated cells (Fig. 4C). These findings indicate that production of NADPH oxidasederived ROS is mediated by the ERK signaling pathway in response to DFO treatment.

\section{Discussion}

The purpose of this study was to investigate the potential effects of DFO on breast cancer cell migration and invasion in vitro and its possible regulatory mechanism. The results showed that DFO enhanced cancer migration and invasion in vitro and NADPH oxidasederived ROS was essential for HIF- $1 \alpha$-dependent migration and invasion induced by DFO, which were mediated by ERK1/2 signaling pathways.

Considering the enhanced dependence on Fe metabolism in cancer cells, previous studies have attempted to use Fe chelators as a therapeutic intervention for breast cancer [911]. As a Fe chelator, DFO is usually beneficial and shows preventive effects related primarily 
to its selective high affinity for $\mathrm{Fe}^{3+}$ and binding in a hexadentate fashion. However, studies have shown that DFO induces HIF-1 $\alpha$ accumulation even under normoxia [32, 33]. Clinical evidence indicates that HIF- $1 \alpha$ is associated with poor prognoses of patients with invasive breast carcinoma [34]. In this study, we examined the effect of DFO on cell migration and invasion, and found a positive effect on these functions. Results also demonstrated that DFO dramatically regulated HIF-1 $\alpha$ expression in MDA-MB-231 cells at the post-transcriptional level, which was involved in DFO-induced cell migration and invasion. Moreover, DFO promoted cell migration and invasion through up-regulation of VEGF and PDK1. These results provide direct evidence that DFO has practical effects on the migration and invasion of breast cancer cells by up-regulation of HIF-1 $\alpha$ expression.

HIF-1 $\alpha$ plays a critical role in the promotion of tumor angiogenesis and metastasis. However, the molecular mechanisms underlying the induction of HIF-1 $\alpha$ in tumor cells are unclear. Recently, a number of studies have suggested that mitochondrial ROS is involved in the stabilization and activation of HIF under hypoxic conditions [35]. Moreover, increased ROS and ROS-dependent stabilization of HIF under conditions of normal oxygen tension have been reported in cancer cells [36]. DFO is frequently used as a hypoxic-mimetic agent, which has been shown to mimic the effects of oxygen deprivation by inducing a number of hypoxia-response genes [37]. Notably, DFO may increase the production of hydroxyl radicals and exert pro-oxidant and cytotoxic effects [38-40]. These findings show that ROS is mediated through up-regulation of HIF- $1 \alpha$. Consistent with these reports, our results clearly suggested that increased ROS production was required for HIF-1 $\alpha$ stabilization induced by DFO, and these effects were attenuated by a NADPH oxidase inhibitor. We also revealed that high levels of ROS production resulted in enhanced cell migration and invasion. Conversely, a decrease of ROS activity induced by the NADPH oxidase inhibitor suppressed cell migration and invasion. Taken together, the present study suggests that DFO treatment of breast cancer cells with high ROS production promotes breast cancer metastasis through up-regulation of HIF-1 $\alpha$ expression.

Elevated ROS generation is associated with alterations of metastatic genes in malignant breast cancer cell lines [41]. Previous studies show that ROS can activate downstream PI3K/AKT and ERK1/2 pathways that regulate HIF-1 and VEGF expression [42, 43]. Shi et al. reported that bFGF induces HIF-1 $\alpha$ activation and VEGF release in the T47D breast cancer cell line, involving PI3K/Akt and MEK1/ERK pathways [24]. Furthermore, ERK1/2 translocation to the nucleus to exert part of its biological activity is promoted by hypoxia [44]. Phosphorylation of p300 by ERK increases HIF- $1 \alpha$ transcriptional activity by increasing formation of the HIF-1/p300 complex [45]. In the present study, DFO treatment up-regulated ERK1/2 phosphorylation in the breast cancer cell line MDA-MB-231. To further test whether DFO-induced ERK1/2 activation specifically regulated cell migration and invasion, we used PD98059, a specific inhibitor of the upstream ERK regulator MEK1, to suppress the ERK1/2 pathway. After treatment with the cell, $100 \mu \mathrm{M}$ PD98059 was sufficient to downregulate ERK1/2 activation to basal levels without nonspecific effects (data not shown). Furthermore, reduced phosphorylation of ERK1/2 was observed after inhibition of ROS production, which correlated with cell migration and invasion. Thus, these results suggest a dependency of ROS on ERK1/2 signaling pathways and HIF-1 $\alpha$ expression in MDA-MB-231 cells. Accordingly, it may be reasonable to speculate that DFO-induced enhancement of HIF$1 \alpha$ protein stabilization is in part mediated through the ERK1/2 pathway.

In conclusion, the present study strengthens the hypothesis that Fe chelation with DFO may have the unintended effect of promoting breast cancer metastasis by increasing HIF- $1 \alpha$ expression. Our results show that DFO significantly enhances breast cancer cell migration and invasion in vitro. Furthermore, NADPH oxidase-derived ROS is essential for DFO-induced cell migration and invasion through up-regulation of HIF-1 $\alpha$ expression. It is very likely that ROS mediates stabilization of HIF- $1 \alpha$ protein through the ERK1/2 pathway. Based on these findings, we propose that accumulation of HIF- $1 \alpha$ is a critical step for DFO-induced cell migration and invasion, which may potentially lead to metastasis and recurrence of breast cancer. 
Liu et al.: DFO-Induced Cell Migration and Invasion

\section{Disclosure Statement}

None.

\section{Acknowledgements}

This project was supported by grants from the National Natural Science Foundation of China (30901170 and 81200298).

\section{References}

1 Kwok JC, Richardson DR: The iron metabolism of neoplastic cells: alterations that facilitate proliferation? Crit Rev Oncol Hematol 2002;42:65-78.

-2 Rehman S, Husnain SM: A Probable Risk Factor of Female Breast Cancer: Study on Benign and Malignant Breast Tissue Samples. Biol Trace Elem Res 2014;157:24-29.

3 Cui Y, Vogt S, Olson N, Glass AG, Rohan TE: Levels of zinc, selenium, calcium, and iron in benign breast tissue and risk of subsequent breast cancer. Cancer Epidemiol Biomarkers Prev 2007;16:1682-1685.

4 Singh M, Mugler K, Hailoo DW, Burke S, Nemesure B, Torkko K, Shroyer KR: Differential expression of transferrin receptor (TfR) in a spectrum of normal to malignant breast tissues: implications for in situ and invasive carcinoma. Appl Immunohistochem Mol Morphol 2011;19:417-423.

-5 Habashy HO, Powe DG, Staka CM, Rakha EA, Ball G, Green AR, Aleskandarany M, Paish EC, Douglas Macmillan R, Nicholson RI, Ellis IO, Gee JM: Transferrin receptor (CD71) is a marker of poor prognosis in breast cancer and can predict response to tamoxifen. Breast Cancer Res Treat 2010;119:283-293.

6 Shpyleva SI, Tryndyak VP, Kovalchuk O, Starlard-Davenport A, Chekhun VF, Beland FA, Pogribny IP: Role of ferritin alterations in human breast cancer cells. Breast Cancer Res Treat 2011;126:63-71.

7 Pahl PM, Horwitz MA, Horwitz KB, Horwitz LD: Desferri-exochelin induces death by apoptosis in human breast cancer cells but does not kill normal breast cells. Breast Cancer Res Treat 2001;69:69-79.

8 Kulp KS, Vulliet PR: Mimosine blocks cell cycle progression by chelating iron in asynchronous human breast cancer cells. Toxicol Appl Pharmacol 1996;139:356-364.

-9 Hoke EM, Maylock CA, Shacter E: Desferal inhibits breast tumor growth and does not interfere with the tumoricidal activity of doxorubicin. Free Radic Biol Med 2005;39:403-411.

10 Jiang XP, Wang F, Yang DC, Elliott RL, Head JF: Induction of apoptosis by iron depletion in the human breast cancer MCF-7 cell line and the $13762 \mathrm{NF}$ rat mammary adenocarcinoma in vivo. Anticancer Res 2002;22:2685-2692.

11 Reddel RR, Hedley DW, Sutherland RL: Cell cycle effects of iron depletion on T-47D human breast cancer cells. Exp Cell Res 1985;161:277-284.

12 Dongiovanni P, Valenti L, Ludovica Fracanzani A, Gatti S, Cairo G, Fargion S: Iron depletion by deferoxamine up-regulates glucose uptake and insulin signaling in hepatoma cells and in rat liver. Am J Pathol 2008;172:738-747.

13 Salnikow K, Donald SP, Bruick RK, Zhitkovich A, Phang JM, Kasprzak KS: Depletion of intracellular ascorbate by the carcinogenic metals nickel and cobalt results in the induction of hypoxic stress. J Biol Chem 2004;279:40337-40344.

14 Bertout JA, Patel SA, Simon MC: The impact of 02 availability on human cancer. Nat Rev Cancer 2008;8:967-975.

15 Bos R, van der Groep P, Greijer AE, Shvarts A, Meijer S, Pinedo HM, Semenza GL, van Diest PJ, van der Wall E: Levels of hypoxia-inducible factor-1alpha independently predict prognosis in patients with lymph node negative breast carcinoma. Cancer 2003;97:1573-1581.

-16 Schindl M, Schoppmann SF, Samonigg H, Hausmaninger H, Kwasny W, Gnant M, Jakesz R, Kubista E, Birner P, Oberhuber G, Austrian Breast and Colorectal Cancer Study Group: Overexpression of hypoxia-inducible factor 1 alpha is associated with an unfavorable prognosis in lymph node-positive breast cancer. Clin Cancer Res 2002;8:1831-1837. 
17 Yamamoto Y, Ibusuki M, Okumura Y, Kawasoe T, Kai K, Iyama K, Iwase H: Hypoxia-inducible factor 1alpha is closely linked to an aggressive phenotype in breast cancer. Breast Cancer Res Treat 2008;110:465-475.

-18 Chandel NS, McClintock DS, Feliciano CE, Wood TM, Melendez JA, Rodriguez AM, Schumacker PT: Reactive oxygen species generated at mitochondrial complex III stabilize hypoxia-inducible factor-1alpha during hypoxia: a mechanism of 02 sensing. J Biol Chem 2000;275:25130-25138.

19 Guzy RD, Hoyos B, Robin E, Chen H, Liu L, Mansfield KD, Simon MC, Hammerling U, Schumacker PT: Mitochondrial complex III is required for hypoxia-induced ROS production and cellular oxygen sensing. Cell Metab 2005;1:401-408.

20 Schroedl C, McClintock DS, Budinger GR, Chandel NS: Hypoxic but not anoxic stabilization of HIF-1alpha requires mitochondrial reactive oxygen species. Am J Physiol Lung Cell Mol Physiol 2002;283:L922-L931.

21 Biswas S, Gupta MK, Chattopadhyay D, Mukhopadhyay CK: Insulin-induced activation of hypoxia-inducible factor-1 requires generation of reactive oxygen species by NADPH oxidase. Am J Physiol Heart Circ Physiol 2007;292:H758-H766.

22 Fandrey J, Frede S, Jelkmann W: Role of hydrogen peroxide in hypoxia-induced erythropoietin production. Biochem J 1994;303:507-510.

23 Haddad JJ, Land SC: A non-hypoxic, ROS-sensitive pathway mediates TNF-alpha-dependent regulation of HIF-1alpha. FEBS Lett 2001;505:269-274.

24 Shi YH, Wang YX, Bingle L, Gong LH, Heng WJ, Li Y, Fang WG: In vitro study of HIF-1 activation and VEGF release by bFGF in the T47D breast cancer cell line under normoxic conditions: involvement of PI-3K/Akt and MEK1/ERK pathways. J Pathol 2005;205:530-536.

25 Callapina M, Zhou J, Schmid T, Köhl R, Brüne B: NO restores HIF-1alpha hydroxylation during hypoxia: role of reactive oxygen species. Free Radic Biol Med 2005;39:925-936.

26 Wartenberg M, Ling FC, Müschen M, Klein F, Acker H, Gassmann M, Petrat K, Pütz V, Hescheler J, Sauer H: Regulation of the multidrug resistance transporter P-glycoprotein in multicellular tumor spheroids by hypoxia-inducible factor (HIF-1) and reactive oxygen species. FASEB J 2003;17:503-505.

27 Vaux EC, Metzen E, Yeates KM, Ratcliffe PJ: Regulation of hypoxia-inducible factor is preserved in the absence of a functioning mitochondrial respiratory chain. Blood 2001;98:296-302.

28 Zhang W, Wu Y, Yan Q, Ma F, Shi X, Zhao Y, Peng Y, Wang J, Jiang B: Deferoxamine enhances cell migration and invasion through promotion of HIF-1 $\alpha$ expression and epithelial-mesenchymal transition in colorectal cancer. Oncol Rep 2014;31:111-116.

29 Goyal P, Weissmann N, Grimminger F, Hegel C, Bader L, Rose F, Fink L, Ghofrani HA, Schermuly RT, Schmidt HH, Seeger W, Hänze J: Upregulation of NAD(P)H oxidase 1 in hypoxia activates hypoxia-inducible factor 1 via increase in reactive oxygen species. Free Radic Biol Med 2004;36:1279-1288.

-30 Adachi Y, Shibai Y, Mitsushita J, Shang WH, Hirose K, Kamata T: Oncogenic Ras upregulates NADPH oxidase 1 gene expression through MEK-ERK-dependent phosphorylation of GATA-6. Oncogene 2008;27:49214932.

-31 Rathnasamy G, Ling EA, Kaur C. Hypoxia inducible factor- $1 \alpha$ mediates iron uptake which induces inflammatory response in amoeboid microglial cells in developing periventricular white matter through MAP kinase pathway. Neuropharmacology 2014;77:428-440.

-32 Martínez-Romero R, Martínez-Lara E, Aguilar-Quesada R, Peralta A, Oliver FJ, Siles E: PARP-1 modulates deferoxamine-induced HIF-1alpha accumulation through the regulation of nitric oxide and oxidative stress. J Cell Biochem 2008;104:2248-2260.

-33 Wu Y, Li X, Xie W, Jankovic J, Le W, Pan T: Neuroprotection of deferoxamine on rotenone-induced injury via accumulation of HIF-1alpha and induction of autophagy in SH-SY5Y cells. Neurochem Int 2010;57:198205.

-34 Dales JP, Garcia S, Meunier-Carpentier S, Andrac-Meyer L, Haddad O, Lavaut MN, Allasia C, Bonnier P, Charpin C: Overexpression of hypoxia-inducible factor HIF-1alpha predicts early relapse in breast cancer: retrospective study in a series of 745 patients. Int J Cancer 2005;116:734-739.

-35 Schroedl C, McClintock DS, Budinger GR, Chandel NS: Hypoxic but not anoxic stabilization of HIF-1alpha requires mitochondrial reactive oxygen species. Am J Physiol Lung Cell Mol Physiol 2002;283:L922-L931.

-36 Guzy RD, Hoyos B, Robin E, Chen H, Liu L, Mansfield KD, Simon MC, Hammerling U, Schumacker PT: Mitochondrial complex III is required for hypoxia-induced ROS production and cellular oxygen sensing. Cell Metab 2005;1:401-408. 
37 Mu D, Chang YS, Vexler ZS, Ferriero DM: Hypoxia-inducible factor 1alpha and erythropoietin upregulation with deferoxamine salvage after neonatal stroke. Exp Neurol 2005;195:407-415.

- 38 Lee YS, Wurster RD: Deferoxamine-induced cytotoxicity in human neuronal cell lines: protection by free radical scavengers. Toxicol Lett 1995;78:67-71.

-39 Becton DL, Bryles P: Deferoxamine inhibition of human neuroblastoma viability and proliferation. Cancer Res 1988;48:7189-7192.

40 Klebanoff SJ, Waltersdorph AM, Michel BR, Rosen H: Oxygen-based free radical generation by ferrous ions and deferoxamine. J Biol Chem 1989;264:19765-19771.

-41 Echiburú-Chau C, Roy D, Calaf GM: Metastatic suppressor CD44 is related with oxidative stress in breast cancer cell lines. Int J Oncol 2011;39:1481-1489.

42 Shi YH, Wang YX, Bingle L, Gong LH, Heng WJ, Li Y, Fang WG: In vitro study of HIF-1 activation and VEGF release by bFGF in the T47D breast cancer cell line under normoxic conditions: involvement of PI-3K/Akt and MEK1/ERK pathways. J Pathol 2005;205:530-536.

-43 Nogueira V, Park Y, Chen CC, Xu PZ, Chen ML, Tonic I, Unterman T, Hay N: Akt determines replicative senescence and oxidative or oncogenic premature senescence and sensitizes cells to oxidative apoptosis. Cancer Cell 2008;14:458-470.

44 Brunet A, Roux D, Lenormand P, Dowd S, Keyse S, Pouysségur J: Nuclear translocation of p42/p44 mitogenactivated protein kinase is required for growth factor-induced gene expression and cell cycle entry. EMBO J 1999;18:664-674.

45 Sang N, Stiehl DP, Bohensky J, Leshchinsky I, Srinivas V, Caro J: MAPK signaling up-regulates the activity of hypoxia-inducible factors by its effects on p300. J Biol Chem 2003;278:14013-14019. 